\title{
Reviews of Independent Press Books in Counterpoise and Other Publications
}

\author{
Juris Dilevko and Keren Dali
}

\begin{abstract}
Although Counterpoise claims that it reviews books that are reviewed by other publications either infrequently or not at all, almost three-quarters of the books $(74.7 \%)$ reviewed by Counterpoise are reviewed by a wide variety of other publications, including popular magazines and newspapers. Four core library review tools (Booklist, Choice, Library Journal, and Publishers Weekly) review 48.2 percent of all book titles reviewed by Counterpoise, and their reviews are favorable 74.4 percent of the time. Of the books not reviewed anywhere else except Counterpoise, more than half fall into six Library of Congress classification categories, including $\mathrm{E}$ (History: America), HQ (The family. Marriage. Women), HV (Social pathology. Social and public welfare. Criminology), and HD (Industries. Land use. Labor). In addition, there is a subset of titles that are frequently and positively reviewed by popular and academic publications, but not by reviewing journals commonly used by librarians.
\end{abstract}

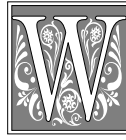

ithin the field of librarianship, Counterpoise claims to serve a unique purpose. Founded in 1997 by Charles Willett, it prides itself on being "the only review journal that makes alternative points of view widely accessible to librarians, scholars and activists." ${ }^{\prime 1}$ An outgrowth of the Social Responsibilities Round Table (SRRT) of the ALA, then briefly a part of CRISES Press (owned by Willett), and currently a venture of the Civic Media Center, a nonprofit alternative library in Gainesville, Florida, Counterpoise publishes, among other items, "original essays; comparative review articles; and many careful reviews of books, periodicals and non-print materials overlooked by other review journals." ${ }^{2,3}$ As such, it sees its mission as providing a counterbalance to mainstream and corporate media outlets. As Willett comments in the Editor's Notes of the inaugural issue of Counterpoise, one of the journal's founding premises is, "If we castigate the New York Times for its news bias, why trust its book reviews? And what about mainstream library journals-aren't they wedded to profit, fame and privilege.... Review journals, aping commerce and government, have chosen money as their first variable." ${ }^{\prime 4}$ As a result, mainstream journals and newspapers have a tendency to review materials that are produced by large, corporate-controlled publishers who have significant marketing and advertising budgets. Such mainstream venues may not necessarily present "alterna-

Juris Dilevko and Keren Dali are members of the Faculty of Information Studies at the University of Toronto; e-mail: dilevko@fis.utoronto.ca and dali@fis.utoronto.ca. 
tive points of view encouraging social responsibility, liberty and dissent, as affirmed by the Universal Declaration of Human Rights, The Bill of Rights of the U.S. Constitution, the Library Bill of Rights, the Talloires Declaration (academic environmental stewardship), the Valdez Principles (corporate environmental responsibility), and related docu-

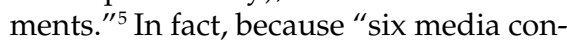
glomerates and the public relations industry-operating in close association with corporations, governments and universities-control the production and dissemination of most mainstream information and entertainment, concerned librarians, educators and activists around the world look to Counterpoise for access to materials and ideas that liberate the mind and defend democracy, peace, social justice, and the environment." ${ }^{\prime 6}$ This is especially true because "[w] hat distinguishes Counterpoise from review journals that just mirror the global, profit-oriented, capitalist culture is its concern for positive social change; what distinguishes it from other alternative journals is the breadth, depth and reliability of its coverage." 7

Invoking the names of Howard Zinn, author of A People's History of the United States, and Edward Herman, author of an essay entitled "Toward a Democratic Media" and coauthor with Noam Chomsky of Manufacturing Consent: The Political Economy of the Mass Media, Willett suggests that for-profit media follow an agenda that perpetuates historical bias by telling stories from the point of view of victors, not victims. On the other hand, the ideas and publications of the alternative press are "often ignored, misrepresented or suppressed by corporate and government media, ${ }^{8}$ despite the fact that, taken collectively, the alternative press is "an enormous body of books, pamphlets, magazines, zines, and audiovisual and electronic materials presenting socially responsible knowledge, points of view and choices." ${ }^{\prime 9}$ In short, the alternative press is "a democratic media organized and controlled by ordinary citizens and their grassroots organizations."10 Given this background, Counterpoise "describes, criticizes, defends and promotes these [alternative] publications and products against this bias,"11 that is, the bias of being overlooked by mainstream reviewing publications. And, as Willett suggests at the conclusion of his editorial, fighting against the bias of "money-oriented, mainstream review journals" is a neverending "struggle" that calls for a steady infusion of monetary resources. ${ }^{12}$

\section{Literature Review}

The mere existence of a publication such as Counterpoise testifies to the lively debate within librarianship about the efficacy of reviewing tools, especially with regard to what Willett identifies as the alternative press. The explosive growth of small presses (or alternative presses) in the 1960s and 1970s caused the library community to ask itself hard questions about the degree to which publications of these small presses (or alternative presses) were being collected by libraries. The views of scholars such as Ross Atkinson, who noted that a novel reviewed on the front page of the New York Times Book Review would be purchased by libraries "regardless of who wrote the novel, where it was published, what it is about, or even what the review says about it"13 and that academic titles reviewed in core journals will invariably be acquired, led others to ponder the responsibility of libraries in collecting small press titles that may not be reviewed at all, let alone in core journals.

In 1984, Judith Serebnick and John Cullars observed that 47.2 percent of small press titles published in 1980 received at least one review, with ten journals publishing 54.3 percent of those reviews. ${ }^{14}$ In 1992, Serebnick reported that, of 450 small press titles published in 1986, only 38.9 percent received at least one review and only twelve titles received six or more reviews each. ${ }^{15}$ As in her earlier study, a small number of journals (14) accounted for a majority of all reviews $(53.4 \%) .{ }^{16}$ Journals most frequently re- 
viewing small press titles were Booklist, Choice, Library Journal, and Publishers Weekly, each with more than twenty reviews of such titles. ${ }^{17}$ In 2000, Juris Dilevko and Alison Hayman demonstrated that both Library Journal and the New York Times Book Review consistently reviewed independently published fiction titles "at a rate of between $30 \%$ and $40 \%$ of all fiction titles" reviewed by each publication in 1994-1997 (Library Journal, 35.3\%; New York Times Book Review, $37.2 \%) .{ }^{18}$ These two publications therefore reviewed corporately published books at a rate of 64.7 percent and 62.8 percent, respectively, of all published books-a percentage that "quite closely parallels the market share of the seven corporate publishers (66.2\% in 1997), according to figures supplied by Book Publishing Report."19 Given the fact that the presence or absence of reviews of small press titles is positively related to the number of libraries owning such titles, ${ }^{20}$ much energy has been devoted to making publications of all types more cognizant of small presses and thus more amenable to reviewing the books produced by them. Nevertheless, believing that these efforts were insufficient, Willett founded Counterpoise in 1997.

\section{Purpose}

Before outlining the purpose of this article, a word needs to be said about the use of the terms "small press" or "alternative press." First, the very concept of small press is problematic because it has undergone a major transformation from the BC era ("before personal computers" or "prior to 1980 ") to the beginning of the twenty-first century. ${ }^{21}$ Indeed, the evolution has been such that Tom Person suggests replacing "small press" with the more pragmatic term "independent publishing" or "independent press," which he defines as "a company that does not belong to another company or corporation." ${ }^{22}$ From this point of view, then, the terms "small press," "independent press," and "alternative press" are synonymous because these presses produce titles that present an alternative to main- stream or corporate publishers. Michael Albert agrees with this formulation, noting that "an alternative media institution (to the extent possible given its circumstances) doesn't try to maximize profits, doesn't primarily sell audience to advertisers for revenues (and so seeks broad and non-elite audience), is structured to subvert society's defining hierarchical social relationships, and is structurally profoundly different from and as independent of other major social institutions, particularly corporations, as it can be."23 Of course, "society's defining hierarchical social relationships" can be subverted from both the left wing and the right wing and thus, from a political, social, or cultural perspective, the independent or alternative press can be either leftist (sometimes called progressive) or rightist.

Notwithstanding discussions about the intricacies of terminology, Counterpoise has effectively positioned itself as one of the few champions of oppressed and neglected voices paying concerted attention to publications produced, in general, by the "progressive or leftist" alternative (or independent) press. ${ }^{24} \mathrm{Col}-$ lection development librarians in many universities and colleges in the United States and Canada, convinced that Counterpoise reviews materials that are rarely reviewed elsewhere, subscribe to Counterpoise so that they can keep up with these kinds of alternative publications. ${ }^{25}$ However, is it really the case that other publications do not review the titles reviewed by Counterpoise and that titles published by leftist or progressive alternative presses are overlooked, ignored, misrepresented, or suppressed by such "money-oriented" media as Library Journal, Publishers Weekly, the New York Times, and others? The purpose of the present article is to examine these issues in detail through the following six research questions:

1. How many of the titles reviewed in Counterpoise were reviewed at least once in another publication?

2. Which types of publications (i.e., library review journals, academic jour- 
nals, newspapers, magazines, etc.) reviewed Counterpoise-reviewed titles, and how often did they do so?

3. What was the general tone (i.e., favorable, mixed, unfavorable, etc.) of the reviews of Counterpoise-reviewed titles that appeared in publications other than Counterpoise?

4. Can any patterns be detected with regard to the subject matter of titles that are reviewed in Counterpoise, but not reviewed in other publications?

5. Can any patterns be detected with regard to the Counterpoise-reviewed titles that also are frequently reviewed in popular and academic publications but are not reviewed in review publications commonly used by library professionals?

6. Can any patterns be detected with regard to the book titles that are reviewed in Counterpoise and also received frequent reviews in other publications?

If the claims made by Counterpoise are valid, namely, that other publications typically do not review the types of titles that it reviews, a case can be made for the utility, even the vital necessity, of public and academic librarians using Counterpoise on a regular basis. Conversely, if other reviewing tools commonly used by librarians are reviewing the same material that Counterpoise claims as its exclusive purview, the claims made by Counterpoise about its singular mission should be revisited and the willingness of other media to review books published by (progressive) independent (or alternative, or small) presses should be acknowledged.

\section{Procedures}

All titles reviewed in the Book Reviews section of Counterpoise for the four-year period 1997-2000 formed the basis of this study. That is, the researchers worked from the list of books that Counterpoise editors had chosen to include in their Book Reviews section; the assumption here is that, by their very presence in Counterpoise, those titles present the kind of alternative viewpoints that mark them as the types of titles published by alternative presses. Counterpoise also has sepa- rate sections that review reference titles, magazines, pamphlets, zines, comics, and audiovisual materials, but the present study did not include these titles. ${ }^{26} \mathrm{Be}-$ tween 1997 and 2000, the Book Reviews section of Counterpoise consisted of 434 unique titles (453 total titles minus 19 duplicates). Identifying information (title, author/editor, publisher, place of publication, year of publication, etc.) about each of those 434 titles was entered into an Excel spreadsheet. A unique identifying code was assigned to each title (e.g., A46, B78, C159, D231). To track the subject matter of titles, the researchers also recorded subject headings and the broad Library of Congress (LC) classification number assigned to the titles listed in tables 7 through 10 below, as found in the Online Computer Library Center (OCLC) WorldCat database.

Then, using the ProQuest database, the researchers searched for the presence of book reviews for each of the 434 titles in the thousands of publications indexed by ProQuest. From the "Search Methods" menu, the researchers chose "Guided Search"; article type was set as "book review." Both current and back file databases were searched. Retrieved hits were scanned for relevancy (i.e., the researchers ensured that the retrieved review did, in fact, review the title in question) and marked, if relevant. "Marked list \& durable links" from "Results \& Marked List" was displayed. Using the "Export Citations" feature of ProQuest, complete bibliographical information about each relevant review was exported to the bibliographic software package EndNote and subsequently transferred to an Excel spreadsheet.

In addition to the necessary identifying information, the following fields were created for each review: source title; publication type; and review type. The publication type of each review was categorized as follows:

A. core library reviewing journals (Booklist, Choice, Library Journal, and Publishers Weekly);

B. other reviewing publications com- 
monly used by librarians (e.g., New York Times Book Review, Women's Review of Books, Times Literary Supplement, World Literature Today, etc.);

C. newspapers and large-circulation popular magazines (e.g., Chicago Tribune, Los Angeles Times, The Nation, Village Voice, Washington Post, etc.);

D. consumer magazines and trade publications as identified by the 2002 online version of Ulrich's Periodicals Directory;

E. academic/scholarly publications as identified by the 2002 online version of Ulrich's Periodicals Directory.

In reporting data below, category A was occasionally split into two subcategories. Publishers Weekly (category A-1) was place in one subcategory, and Booklist, Choice, and Library Journal (category A-2) were placed in the other subcategory. In addition, categories A and B were sometimes combined to form a supercategory that could be thought of as professional reviewing tools and categories $\mathrm{C}$ and $\mathrm{D}$ were sometimes combined into a supercategory that could be thought of as popular publications. Finally, categories $A$ and $B$ sometimes were juxtaposed with categories $\mathrm{C}, \mathrm{D}$, and $\mathrm{E}$ to make the distinction between, on the one hand, professional reviewing tools and, on the other, publications (both popular and academic) that were not primarily review oriented. Review type was derived from the classification of reviews provided by ProQuest: favorable, unfavorable, mixed, comparative, and rating not present. ${ }^{27}$ The categories of "comparative" and "not present" were combined to form a category of "not rated." All spreadsheets and databases were linked and queried by means of the unique identification code assigned each Counterpoise-reviewed title. All procedures were carried out in January-February 2003.

This study method thus differs slightly from the work of Serebnick mentioned above. She and her colleagues chose random book titles from the Small Press Record of Books in Print and then determined the extent to which those titles were reviewed in book review indexes, whereas the researchers of this study began with book titles that already had been reviewed by Counterpoise in order to generate a list of independent press titles for which the researchers subsequently determined the presence or absence of reviews in a variety of other publications.

\section{Results \\ Number and Frequency of Reviews in Other Publications}

Of the 434 unique book titles reviewed in Counterpoise between 1997 and 2000, 324 $(74.7 \%)$ generated at least one other book review in a publication indexed by ProQuest (first research question). More specifically, 249 Counterpoise-reviewed

\section{TABLE 1}

Book Titles Reviewed and Not Reviewed by Professional Reviewing Tools (Category A and B Publications) That Were Reviewed by Academic and Popular Publications (Category C, D, and E Publications)

\begin{tabular}{|c|c|c|c|c|}
\hline \multirow{3}{*}{ Not reviewed in category } & \multicolumn{4}{|c|}{ Number of Reviews in Category C, D, and E Publications } \\
\hline & One (\%) & Two (\%) & Three or more $(\%)$ & Total \\
\hline & & & & \\
\hline A and $\mathrm{B}$ publications & $39(40.6)^{*}$ & $19(38.8)$ & $17(18.3)$ & $75(31.5)$ \\
\hline Reviewed in category & & & & \\
\hline $\mathrm{A}$ and $\mathrm{B}$ publications & $57(59.3)^{*}$ & $30(61.2)$ & $76(81.7)$ & $163(68.5)$ \\
\hline Totals & 96 (100) & $49(100)$ & $93(100)$ & $238(100)$ \\
\hline
\end{tabular}




\begin{tabular}{|lc|}
\hline \multicolumn{2}{|c|}{ TABLE 2} \\
\multicolumn{2}{|c|}{$\begin{array}{c}\text { Number of Reviews in Other } \\
\text { Publications of Book Titles } \\
\text { Reviewed in }\end{array}$} \\
\hline \hline Counterpoise \\
Number of & Number of \\
Book Reviews & Titles (\%) \\
\hline One & $87(26.9)$ \\
Two & $68(21.0)$ \\
Three to five reviews & $106(32.7)$ \\
Six to ten reviews & $48(14.8)$ \\
More than 10 reviews & $15(4.6)$ \\
\hline Total & $\mathbf{3 2 4}(\mathbf{1 0 0 )}$ \\
\hline
\end{tabular}

titles $(57.4 \%)$ generated at least one review in either the four core library reviewing publications (category A) or other reviewing publications commonly used by librarians (category B). Of these 249 titles reviewed by category A and category B publications, $163(65.5 \%)$ also were reviewed by category C, D, or E publications. More specifically still, only 209 (out of 434) Counterpoise-reviewed titles $(48.2 \%)$ generated at least one review in category A publications (Booklist, Choice, Library Journal, and Publishers Weekly). Conversely, 238 (out of 434) Counterpoisereviewed titles $(54.8 \%)$ generated at least one review in category $\mathrm{C}, \mathrm{D}$, or E publications. Of these 238 titles, 72 also were reviewed in Publishers Weekly; 132 also were reviewed in either Booklist, Choice, or Library Journal; and 68 also were reviewed in category B publications. Moreover, of these 238 titles generating at least one review in a category C, D, or E publication, 96 generated a single review, 49 generated two reviews, and 93 generated three or more reviews. Table 1 shows the extent to which category A and B publications (professional reviewing tools) reviewed book titles that were reviewed by category C, D, and E publications. Professional reviewing tools used by librarians did not review 75 book titles (31.5\%) that were reviewed by popular and academic publications (categories C, D, and E). Of these 75 titles, 19 had received two reviews and another 17 had received three or more reviews. The four core library reviewing tools (category A publications alone) did not review 115 publications that were reviewed by category B, C, D, and $\mathrm{E}$ publications. Generally speaking, however, the more reviews that a Counterpoise-reviewed title received in category C, D, and E publications, the greater the chance that it also was reviewed in category A and B publications (table 1). For instance, of the 93 Counterpoise-reviewed titles that were reviewed three or more times in category C, D, and E publications, 76 (81.7\%) were reviewed in a category A and B publication, whereas of the 96 Counterpoise-reviewed titles that were reviewed once in a category C, D, and E publication, only 57 $(59.3 \%)$ were reviewed in a category A and B publication. In total, the 324 titles generated 1,225 reviews across all types of publications in ProQuest.

Table 2 shows the frequency of reviews per book title. Of the 324 titles reviewed by other publications, a plurality $(32.7 \%)$ was reviewed between three and five times, with a further 14.8 percent of titles being reviewed between six and ten times. Overall, 52.2 percent of the titles (169) were reviewed three or more times in publications other than Counterpoise, and 73.1 percent (237) were reviewed two or more times in publications other than Counterpoise.

What types of publications reviewed Counterpoise-reviewed book titles (second research question)? As indicated in table 3 , the four core library reviewing journals produced 30 percent $(8.1 \%+21.9 \%)$ of the total number of reviews (in other publications) of Counterpoise-reviewed titles (367). Newspapers and large-circulation popular magazines produced 15.5 percent (190) of total reviews, and academic/ scholarly journals produced 28 percent (343) of total reviews. Table 4 provides additional details about the publications (within each publication-type category) that reviewed Counterpoise-reviewed publications. For instance, within category B, Lambda Book Report (39) and Women's Review of Books (26) reviewed Counterpoisereviewed titles most frequently, followed by the New York Times Book Review (23) and 
World Literature Today (14). Within category C, The Nation reviewed Counterpoise-reviewed titles most frequently (19), followed by the Los Angeles Times and the San Francisco Chronicle (15 each). Within category D, The Advocate, The Progressive, and Off Our Backs most frequently included reviews of Counterpoise-reviewed titles.

Table 5 approaches research question 2 from a slightly different angle. The researchers wanted to know how often Counterpoise-reviewed titles were reviewed by a specific type of publication, notwithstanding the number of total reviews of that title within each separate publication-type category. For example, if title XYZ was reviewed by three academic/scholarly journals, once by Choice, and once by Library Journal, for the purposes of table 5 , this would be counted as follows: "Title XYZ" was reviewed once by a category E journal and once by the category of core library journals that includes Booklist, Choice, and Library Journal (category A-2). As shown in table 5, then, the 324 titles that were reviewed in publications other than Counterpoise garnered 721 "category reviews." Of these 721 "category reviews," 280 (38.8\%) were in the category of core library reviewing journals (categories A-1 and A-2) and another $181(25.1 \%)$ were in the combined category of newspapers and large-circulation popular magazines, and consumer and trade publications (categories $\mathrm{C}$ and D).

\section{Types of Reviews}

Of the 1,225 total reviews generated by the 324 Counterpoise-reviewed titles that were reviewed in another publication, 748 $(61.1 \%)$ were favorable, $187(15.3 \%)$ were mixed, $42(3.4 \%)$ were unfavorable, and $248(20.2 \%)$ were "not rated" (third research question). As shown in table 6, the rate of favorable reviews was highest in category A-2 publications (78.4\%) and second highest in category A-1 publications $(63.6 \%)$. When categories A-1 and A-2 are combined, the rate of favorable reviews in the four core library journals of Booklist, Choice, Library Journal, and Publishers Weekly is 74.4 percent. The rate of favorable reviews was lowest in combined category $\mathrm{C}$ and $\mathrm{D}$ publications $(53.3 \%)$. When the rate of favorable reviews of all category $A$ and $B$ publications is compared with the rate of favorable reviews of all category C, D, and E publications, it is clear that, taken collectively, the rate at which all professional reviewing tools used by librarians (categories A and B) give favorable reviews $(69.4 \%)$ is greater than the rate at which popular and

\begin{tabular}{|c|c|c|}
\hline \multicolumn{3}{|c|}{$\begin{array}{c}\text { TABLE } 3 \\
\begin{array}{c}\text { Total Number Of Reviews Of Counterpoise-reviewed } \\
\text { Book Titles in Other Publications }\end{array} \\
\end{array}$} \\
\hline Category & $\begin{array}{l}\text { Description of Publications } \\
\text { Belonging to This Category }\end{array}$ & $\begin{array}{l}\text { mber of Total Book } \\
\text { ws in All Publications } \\
\text { n Each Category (\%) }\end{array}$ \\
\hline A-1 & Core library reviewing journal: Publishers Weekly & $99 \quad(8.1)$ \\
\hline A-2 & $\begin{array}{l}\text { Core library reviewing journals: Booklist, Choice, } \\
\text { and Library Journal }\end{array}$ & $268 \quad(21.9)$ \\
\hline $\mathrm{B}$ & Other reviewing journals commonly used by librarians & $149 \quad(12.2)$ \\
\hline $\mathrm{C}$ & Newspapers and large-circulation popular magazines & $190 \quad(15.5)$ \\
\hline $\mathrm{D}$ & Consumer and trade publications & $176 \quad(14.4)$ \\
\hline $\mathrm{E}$ & $\begin{array}{l}\text { Academic/scholarly journals } \\
\text { Total reviews in all publication types }\end{array}$ & $\begin{aligned} & 343(28) \\
& 1,225(100)^{*}\end{aligned}$ \\
\hline
\end{tabular}


TABLE 4

Publications Containing Five or More Reviews for Examined Titles

\begin{tabular}{|c|c|c|}
\hline Type of Publication & Title & $\begin{array}{l}\text { Number } \\
\text { of Reviews }\end{array}$ \\
\hline \multirow{4}{*}{$\begin{array}{l}\text { Core library reviewing journals } \\
\text { (Category A) }\end{array}$} & Library Journal & 110 \\
\hline & Publishers Weekly & 99 \\
\hline & Booklist & 90 \\
\hline & Choice & 68 \\
\hline \multirow{7}{*}{$\begin{array}{l}\text { Other reviewing journals } \\
\text { commonly used by librarians } \\
\text { (Category B) }\end{array}$} & Lambda Book Report & 39 \\
\hline & Women's Review of Books & 26 \\
\hline & New York Times Book Review & 23 \\
\hline & World Literature Today & 14 \\
\hline & School Library Journal & 9 \\
\hline & Times Literary Supplement & 8 \\
\hline & College \& Research Libraries & 5 \\
\hline \multirow{11}{*}{$\begin{array}{l}\text { Newspapers and large-circulation } \\
\text { popular magazines (Category C) }\end{array}$} & The Nation & 19 \\
\hline & Los Angeles Times & 15 \\
\hline & San Francisco Chronicle & 15 \\
\hline & Village Voice & 14 \\
\hline & National Catholic Reporter & 13 \\
\hline & Boston Globe & 11 \\
\hline & Chicago Tribune & 11 \\
\hline & Washington Post & 10 \\
\hline & $M s$ & 9 \\
\hline & Oregonian & 9 \\
\hline & Utne Reader & 7 \\
\hline \multirow{9}{*}{$\begin{array}{l}\text { Consumer and trade } \\
\text { publications (Category D) }\end{array}$} & The Advocate & 11 \\
\hline & The Progressive & 10 \\
\hline & Off Our Backs & 9 \\
\hline & Ecologist & 8 \\
\hline & Hispanic & 7 \\
\hline & Whole Earth & 6 \\
\hline & Communities & 5 \\
\hline & Multinational Monitor & 5 \\
\hline & New Statesman & 5 \\
\hline \multirow{9}{*}{$\begin{array}{l}\text { Academic/scholarly journals } \\
\text { (Category E) }\end{array}$} & Journal of American History & 12 \\
\hline & Monthly Review & 9 \\
\hline & New Scientist & 8 \\
\hline & American Historical Review & 7 \\
\hline & Environmental Politics & 7 \\
\hline & Journal of Women's History & 6 \\
\hline & Labor History & 6 \\
\hline & Alternatives Journal & 5 \\
\hline & NWSA Journal & 5 \\
\hline
\end{tabular}




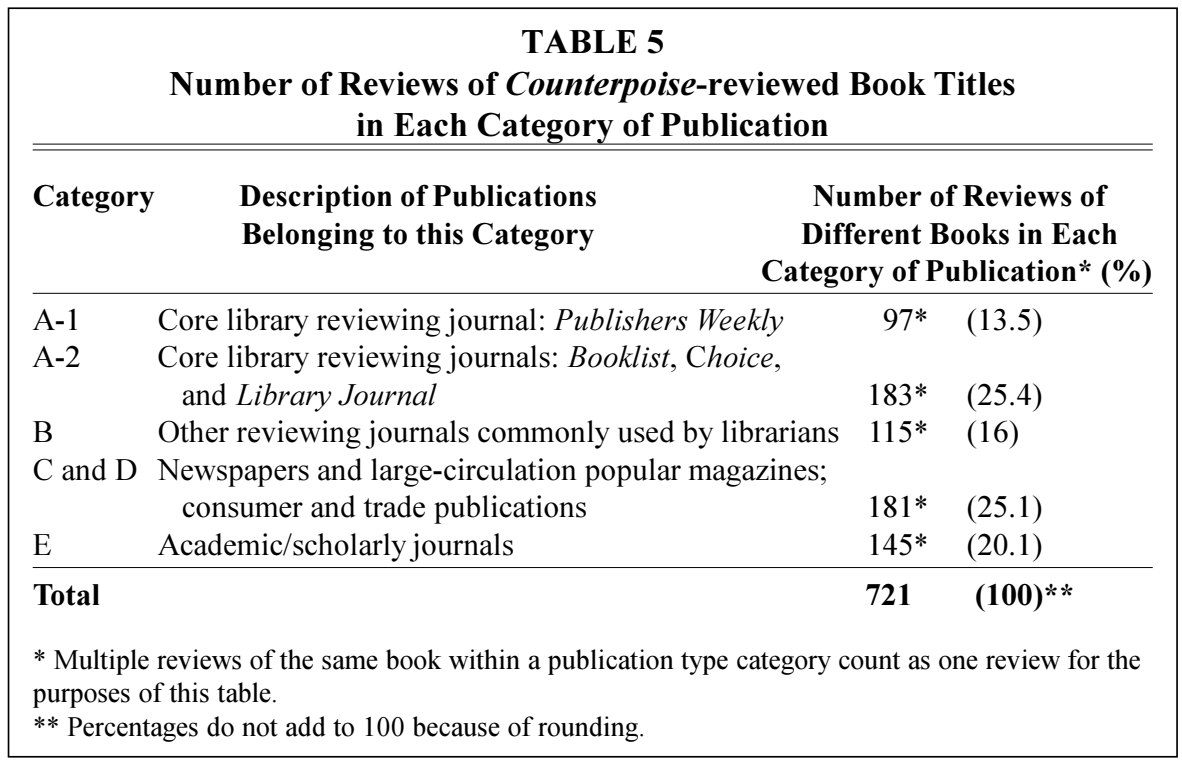

academic publications (categories C, D, and $\mathrm{E}$ ) give favorable reviews (55\%).

In total, 185 Counterpoise-reviewed titles were reviewed favorably at least once in a category C, D, or E publication (popular and academic publications that are not primarily reviewing tools). Of the 185 titles that were reviewed favorably at least once, 50 were not reviewed by category A or category B publications taken as a whole. More specifically, of the 185 titles that were reviewed favorably at least once, 123 were not reviewed by Publishers Weekly (category A-1), 73 were not reviewed by Booklist, Choice, and Library Journal (category A-2), and 125 were not reviewed by any category B publications. Of the 185 titles that were reviewed at least once favorably in a category C, D, or $\mathrm{E}$ publication, 119 were reviewed favorably at least once in a category A or B publication, 40 had at least one mixed re-

TABLE 6

Types of Reviews According to Publication Type

\begin{tabular}{|c|c|c|c|c|}
\hline \multirow{3}{*}{$\frac{\text { Publication Type }}{\text { Category A-1 (99) }}$} & \multirow{3}{*}{$\begin{array}{c}\text { Favorable } \\
63(63.6)\end{array}$} & \multicolumn{2}{|c|}{ Type of Review } & \multirow[b]{2}{*}{ Not Rated } \\
\hline & & Mixed & Unfavorable & \\
\hline & & $27(27.3)$ & $8(8.1)$ & $1 \quad(1)$ \\
\hline Category A-2 (268) & $210(78.4)$ & $35(13.1)$ & $6(2.2)$ & $17 \quad(6.3)$ \\
\hline Category B (149) & $85(57)^{*}$ & $20(13.4)^{*}$ & $4(2.7)^{*}$ & $40(26.8)^{*}$ \\
\hline $\begin{array}{l}\text { Total of categories } \\
\text { A and B (516) }\end{array}$ & $358(69.4)$ & $82(15.9)$ & $18(3.5)$ & 58 (11.2) \\
\hline Category C and D (366) & $195(53.3)$ & $42(11.5)$ & $11(3)$ & $118(32.2)$ \\
\hline Category E (343) & $195(56.9)^{*}$ & $63(18.4)^{*}$ & $13(3.8)^{*}$ & $72(21)^{*}$ \\
\hline $\begin{array}{c}\text { Total of categories of } \\
C, D, \text { and } E(709)\end{array}$ & $390(55)$ & $105(14.8)$ & $24(3.4)$ & $190(26.8)$ \\
\hline Grand total $(1,225)$ & $748(61.1)$ & $187(15.3)$ & $42(3.4)$ & $248(20.2)$ \\
\hline
\end{tabular}


TABLE 7

Library Of Congress (LC) Classifications of Books Reviewed by Counterpoise But Not Reviewed by any Other Publication

LC Main Class/

Subclass Letters

LC Main Class/Subclass Titles

Number of Items

B

Philosophy

BL

DK

Religions. Mythology. Rationalism

Russia. Soviet Union. Former Soviet Republics - Poland 1

DT

E

Africa

3

History: America

F

History: America

3

Environmental sciences

GE

Human ecology. Anthropogeography

GF

Recreation. Leisure

$\mathrm{HC}$

Economic history and conditions

Industries. Land use. Labor

Transportation and communications

Commerce

Sociology (General)

$\mathrm{HN}$

Social history and conditions. Social problems.

Social reform

HQ

The family. Marriage. Women

HV

Social pathology. Social and public welfare.

Criminology

HX

Socialism. Communism. Anarchism

Political theory

$\mathrm{K}$

Law

$\mathrm{L} / \mathrm{LA} / \mathrm{LC}$

Education/History of education/Special aspects of education

$\mathrm{ML}$

Literature on music

$\mathrm{N} / \mathrm{NC}$

$\mathrm{P}$

$\mathrm{PH}$

PJ

Visual Arts/Fine Arts. Drawing. Design. Illustration

Language and literature

Uralic languages. Basque language

Oriental languages and literatures

Literature (General)

English Literature

PN

PR

American Literature

PS

$\mathrm{Q} / \mathrm{QC}$

Science (General)/Physics

R/RA

Medicine (General). Public aspects of medicine

SB

Plant culture

Environmental technology. Sanitary engineering

TD

Home economics

TX

Bibliography. Library science.

Information resources (General) 


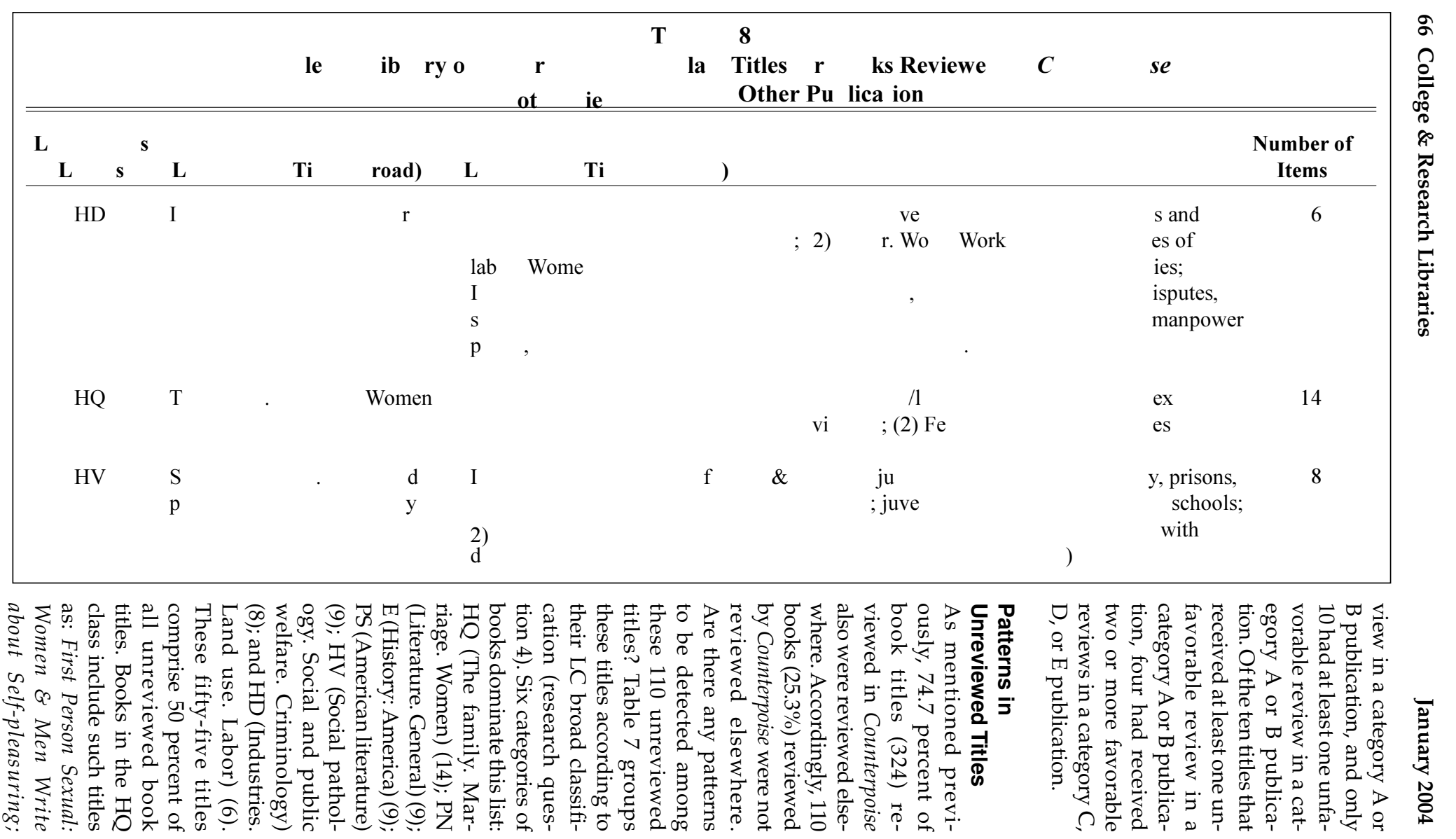


Anal Pleasure \& Health: A Guide for Men and Women; Like There's No Tomorrow: Meditations for Women Leaving Patriarchy; American Sex Machines: The Hidden History of Sex at the U.S. Patent Office; and Much More Than Sexuality: Listening to 70 Gay People Talk about Their Lives. Books in the PN class include: Barbie Unbound: A Parody of the Barbie Obsession; The Solo Sex Joke Book: Jokes, Cartoons, and Limericks about the World's Most Popular Sex Act; and Hot E Bothered: Short Short Fiction on Lesbian Desire. Books in the E class include five titles about various aspects of North American Indian life, as well as Roots of Justice: Stories of Organizing in Communities of Color and Talking about a Revolution. Books in the PS class include two titles with subject headings of "erotic literature" or "erotic stories," as well as fiction and poetry collections from marginalized groups such as Appalachian mountain families, punk rockers, North American Indians, and recent immigrants. Six of the eight books in the HV class deal specifically with the injustices of prisons and/ or the politics of the criminal justice system both in the United States and overseas. Finally, in the HD class, three of the six titles deal with exploited laborers and another title discusses rent strikes and land struggles. (As an example of the types of subclass titles assigned to unreviewed titles in certain LC classes, see table 8 .)

If 110 Counterpoise-reviewed titles were not reviewed at all by any other publications, were some titles reviewed by popular and academic publications (categories C, D, and E), but not by reviewing publications typically used by library professionals (categories A and B) (research question 5)? To get as specific a set as possible of such titles, the researchers generated a list of titles that were reviewed at least three times by category C, D, and E publications with at least one favorable review, but not reviewed by category A and B publications. As shown in table 9, there were sixteen such titles. Nine of the titles are published by small and relatively obscure publishers (Common Courage
Press [3]; New Society Publishers [3]; Aperture [1]; ILR Press [1]; and Orbis Books [1]) that, for the most part, are based in small towns away from the nexus of publishing power (i.e., New York and Boston). Another three publishers could be characterized as small- to medium-sized publishers (New Press, Cleis Press, and South End Press). Two are university presses and the final two are presses connected with political think tanks (Brookings Institute) or government entities (International Labour Organization). With regard to the subject matter of these sixteen books, many, if not all, challenge the fundamental bases of American social and military power (e.g., School of Assassins, Atomic Audit, An Enemy of the State), capitalist economic foundations (e.g., Top Heavy, Juarez, We Are All Leaders), corporate arrogance (e.g., Against the Grain, Our Ecological Footprint), and patriarchal social hierarchies and systems (e.g., Body Alchemy, Natural Eloquence) from what could be described as radical perspectives.

Finally, were there any patterns with regard to the types of books reviewed by Counterpoise and frequently reviewed by other publications (research question 6)? To address this question, the researchers generated a viable list of Counterpoise-reviewed titles that were reviewed ten or more times in all other publications and at least once in category A publications. This allowed the researchers to see whether there were any differences between the kinds of titles not reviewed by library reviewing tools and the kinds of titles that generated numerous reviews across all publication types. As shown in table 10, there were fifteen such books. In comparison with the list of publishers in table 9 , the publishers in table 10 are larger and better known. For example, there are four university press titles, four books from the Free Press in New York, Seal Press in Seattle, and Beacon Press in Boston, and one book from internationally known Blackwell Publishing. Many of these publishers are based in the New York-Boston-Washington corridor. With 
TABLE 9

Book Titles Not Reviewed by Professional Reviewing Tools (Category A or B) but Reviewed at Least Three Times in Popular or Academic Publications (with at least one favorable review)

\begin{tabular}{|c|c|c|c|c|}
\hline $\begin{array}{c}\text { LC Main } \\
\text { Class/Subclass } \\
\text { Letters }\end{array}$ & Book Title & LC Subject Headings & Publisher & $\begin{array}{l}\text { Times Reviewed } \\
\text { in Other } \\
\text { Publications }\end{array}$ \\
\hline BR & $\begin{array}{l}\text { Eternal hostility: The struggle } \\
\text { between theocracy and democracy }\end{array}$ & $\begin{array}{l}\text { Conservatism-Religious aspects-Christianity. Conservatism- } \\
\text { United States-History-20th century. Theocracy. Christian } \\
\text { Coalition. United States-Church history-20th century. } \\
\text { United States-Politics and government-1993-2001. }\end{array}$ & $\begin{array}{l}\text { Common Courage } \\
\text { Press (Monroe, } \\
\text { Maine) }\end{array}$ & 3 \\
\hline E & $\begin{array}{l}\text { Uprooting racism: How white people } \\
\text { can work for racial justice }\end{array}$ & $\begin{array}{l}\text { Racism-United States. Race awareness—United States. } \\
\text { Whites—Race identity-United States. United States—Race } \\
\text { relations. }\end{array}$ & $\begin{array}{l}\text { New Society Publishers } \\
\text { (Gabriola Island, } \\
\text { British Columbia; } \\
\text { Philadelphia) }\end{array}$ & 3 \\
\hline $\mathrm{F}$ & $\begin{array}{l}\text { Landscapes of the interior: Re- } \\
\text { explorations of nature and the } \\
\text { human spirit }\end{array}$ & $\begin{array}{l}\text { Landscape —Canada, Western. Landscape-West (U.S.). } \\
\text { Philosophy of nature. Nature (Aesthetics). Canada, Western- } \\
\text { Description and travel. West (U.S.) - Description and travel. }\end{array}$ & $\begin{array}{l}\text { New Society Publishers } \\
\text { (Gabriola Island, } \\
\text { British Columbia; } \\
\text { Philadelphia) }\end{array}$ & 3 \\
\hline $\mathrm{HC}$ & $\begin{array}{l}\text { Our ecological footprint: Reducing } \\
\text { human impact on the earth }\end{array}$ & $\begin{array}{l}\text { Sustainable development. Nature-Effect of human beings on. } \\
\text { Human ecology. Economic development-Environmental } \\
\text { aspects. }\end{array}$ & $\begin{array}{l}\text { New Society Publishers } \\
\text { (Gabriola Island, } \\
\text { British Columbia; } \\
\text { Philadelphia) }\end{array}$ & 8 \\
\hline $\mathrm{HD}$ & $\begin{array}{l}\text { We are all leaders: The alternative } \\
\text { unionism of the early } 1930 \mathrm{~s}\end{array}$ & $\begin{array}{l}\text { Labor unions-United States-History-20th century. Labor } \\
\text { movement-United States-History-20th century. }\end{array}$ & $\begin{array}{l}\text { University of Illinois } \\
\text { Press }\end{array}$ & 6 \\
\hline HD & $\begin{array}{l}\text { Gender inequality in the labour } \\
\text { market: Occupational concentra- } \\
\text { tion and segregation, a manual of } \\
\text { methodology }\end{array}$ & $\begin{array}{l}\text { Sex discrimination in employment-Data processing- } \\
\text { Methodology. }\end{array}$ & $\begin{array}{l}\text { International Labour } \\
\text { Organization (Geneva, } \\
\text { Switzerland) }\end{array}$ & 3 \\
\hline
\end{tabular}




\begin{tabular}{|c|c|c|c|c|}
\hline \multicolumn{5}{|c|}{$\begin{array}{c}\text { TABLE } 9 \text { (CONT.) } \\
\text { Book Titles Not Reviewed by Professional Reviewing Tools (Category A or B) but Reviewed at Least Three Times in Popular or } \\
\text { Academic Publications (with at least one favorable review) }\end{array}$} \\
\hline $\begin{array}{l}\text { LC Main } \\
\text { Class/Subclass } \\
\text { Letters }\end{array}$ & Book Title & LC Subject Headings & Publisher & $\begin{array}{l}\text { Times Reviewed } \\
\text { in Other } \\
\text { Publications }\end{array}$ \\
\hline HJ & $\begin{array}{l}\text { Top heavy: The increasing inequality } \\
\text { of wealth in America and what can } \\
\text { be done about it }\end{array}$ & Wealth tax-United States. Income distribution-United States. & New Press (New York) & 5 \\
\hline $\mathrm{HN}$ & Juarez: The laboratory of our future & $\begin{array}{l}\text { Ciudad Juarez (Mexico)—Social conditions. Ciudad Juarez } \\
\text { (Mexico)—Economic conditions. }\end{array}$ & Aperture (New York) & 4 \\
\hline HQ & Body alchemy: Transsexual portraits & $\begin{array}{l}\text { Transsexualism-United States. Transsexuals-United States- } \\
\text { Portraits. Transsexuals-United States-Interviews. }\end{array}$ & Cleis Press (Pittsburgh) & 3 \\
\hline $\mathrm{P}$ & $\begin{array}{l}\text { Powers and prospects: Reflections } \\
\text { on human nature and the social } \\
\text { order }\end{array}$ & $\begin{array}{l}\text { Language and languages_-Philosophy. World politics_-1989. } \\
\text { Philosophical anthropology. }\end{array}$ & $\begin{array}{l}\text { South End Press } \\
\text { (Boston) }\end{array}$ & 4 \\
\hline $\mathrm{PN}$ & $\begin{array}{l}\text { An enemy of the state: The life of } \\
\text { Erwin Knoll }\end{array}$ & $\begin{array}{l}\text { Journalists—United States—Biography. War-Press coverage- } \\
\text { United States. }\end{array}$ & $\begin{array}{l}\text { Common Courage Press } \\
\text { (Monroe, Maine) }\end{array}$ & 3 \\
\hline $\mathrm{PN}$ & $\begin{array}{l}\text { Working stiffs, union maids, reds, } \\
\text { and riffraff: An organized guide to } \\
\text { films about labor }\end{array}$ & Working class in motion pictures. & ILR Press (Ithaca, NY) & 6 \\
\hline Q & $\begin{array}{l}\text { Natural eloquence: Women } \\
\text { reinscribe science }\end{array}$ & Women in science. Science news. & $\begin{array}{l}\text { University of } \\
\text { Wisconsin Press }\end{array}$ & 4 \\
\hline $\mathrm{S}$ & $\begin{array}{l}\text { Against the grain: Biotechnology } \\
\text { and the corporate takeover of your } \\
\text { food }\end{array}$ & $\begin{array}{l}\text { Agricultural biotechnology. Food-Biotechnology. Food. } \\
\text { Nutrition. }\end{array}$ & $\begin{array}{l}\text { Common Courage } \\
\text { Press (Monroe, } \\
\text { Maine) }\end{array}$ & 3 \\
\hline
\end{tabular}




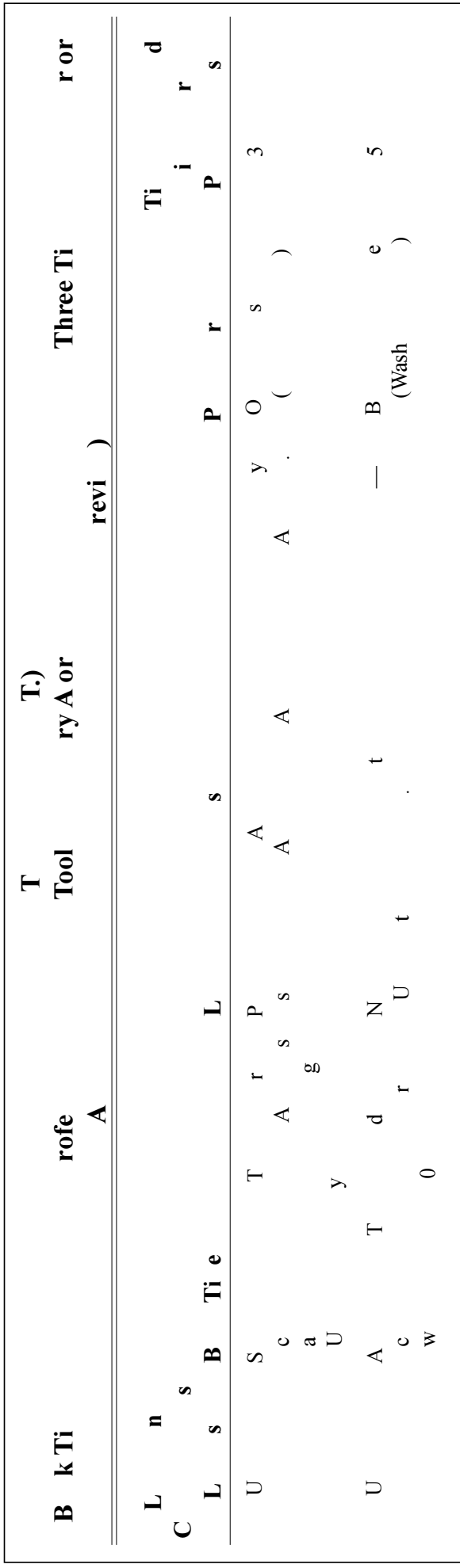

regard to subject matter, there are, to be sure, titles that deal with thorny and difficult issues but, on the whole, the general tone of these books is less provocative (e.g., Justice, Nature and the Geography of Difference; The Old Neighborhood: What We Lost in the Great Suburban Migration, 1966-1999); the topics dealt with seem safer, more conventional, or more historically oriented (e.g., Power Loss: The Origins of Deregulation and Restructuring in the American Electric Utility System), as if it was acceptable to talk about past injustices (e.g., Remembering Slavery: African Americans Talk about Their Personal Experiences of Slavery and Emancipation; Cherokee Women: Gender and Culture Change, 17001835), but not to discuss current ones.

\section{Discussion}

Contrary to the claims of Counterpoise editors, other publications, including mainstream journals and newspapers, are reviewing book titles that present alternative viewpoints on a wide variety of cultural, political, and social issues. Indeed, 74.7 percent of the alternative titles (324 out of 434) reviewed by Counterpoise were reviewed 1,225 times in other publications. (See table 3.) Of these titles, 52.2 percent received three or more reviews. (See table 2.) To be sure, many of these reviews appear in journals such as The Nation, The Progressive, and Multinational Monitor, but many others are printed in the Chicago Tribune, Boston Globe, and Washington Post. (See table 4.) As indicated in table 5, each publication-type category reviews a large number of different alternative titles that have been reviewed by Counterpoise. Popular publications (categories $C$ and $D$ ) review nearly the same number (181) of Counterpoise-reviewed titles as category A-2 publications (183). An individual who reads academic and popular publications (category C, D, and E publications) without glancing at professional reviewing tools (categories A and $B$ ) would find that these publications (categories C, D, and E) covered 238 out of 434 Counterpoise-reviewed titles. (See table 1.) There also was significant over- 


\section{TABLE 10}

Table 10. Counterpoise-reviewed Titles That Were Reviewed Ten or More Times in Other Publications

\begin{tabular}{|c|c|c|c|c|}
\hline $\begin{array}{l}\text { LC Main } \\
\text { Class/Subclass } \\
\text { Letters }\end{array}$ & Book Title & LC Subject Headings & Publisher & $\begin{array}{l}\text { Times Reviewed } \\
\text { in Four Core } \\
\text { Library Reviewing } \\
\text { Journals }\end{array}$ \\
\hline DT & $\begin{array}{l}\text { Woman between two worlds: Portrait } \\
\text { of an Ethiopian rural leader }\end{array}$ & $\begin{array}{l}\text { Women, Gamo-Biography. Gamo (African people)_Politics } \\
\text { and government. }\end{array}$ & $\begin{array}{l}\text { University of Illinois } \\
\text { Press }\end{array}$ & 2 \\
\hline $\mathrm{E}$ & The opening of the American mind & Education, Higher-United States. United States-Intellectual life. & Beacon Press (Boston) & 4 \\
\hline E & $\begin{array}{l}\text { Cherokee women: Gender and } \\
\text { culture change, } 1700-1835\end{array}$ & $\begin{array}{l}\text { Cherokee women-History. Cherokee women-Social condi- } \\
\text { tions. Cherokee Indians-Social life and customs. Sex role- } \\
\text { United States. Sexual division of labor-United States. }\end{array}$ & $\begin{array}{l}\text { University of Nebraska } \\
\text { Press }\end{array}$ & $\mathrm{ra}$ \\
\hline E & $\begin{array}{l}\text { Remembering slavery: African } \\
\text { Americans talk about their } \\
\text { personal experiences of slavery } \\
\text { and emancipation }\end{array}$ & $\begin{array}{l}\text { Slavery-United States-History. African Americans- } \\
\text { Biography. African Americans-History. }\end{array}$ & New Press (New York) & 3 \\
\hline E & $\begin{array}{l}\text { Promoting polyarchy: Globalization, } \\
\text { U.S. intervention, and hegemony }\end{array}$ & $\begin{array}{l}\text { Democracy-History—20th century. Democracy-United } \\
\text { States-History-20th century. World politics-1985-1995. } \\
\text { United States-Foreign relations-1981-1989. United States- } \\
\text { Foreign relations-1989- }\end{array}$ & $\begin{array}{l}\text { Cambridge University } \\
\text { Press }\end{array}$ & 1 \\
\hline GE & $\begin{array}{l}\text { Betrayal of science and reason: How } \\
\text { anti-environmental rhetoric } \\
\text { threatens our future }\end{array}$ & Anti-environmentalism. Environmental degradation. & $\begin{array}{l}\text { Island Press (Washing- } \\
\text { ton, DC) }\end{array}$ & 3 \\
\hline HD & $\begin{array}{l}\text { Power loss: The origins of } \\
\text { deregulation and restructuring in } \\
\text { the American electric utility } \\
\text { system }\end{array}$ & $\begin{array}{l}\text { Electric utilities-Deregulation-United States. Electric } \\
\text { utilities-Government policy-United States-History. Electric } \\
\text { utilities-Law and legislation-United States-History. } \\
\text { Competition-United States-History-20th century. Pressure } \\
\text { groups-United States. }\end{array}$ & MIT Press & 1 \\
\hline
\end{tabular}




\section{TABLE 10 (CONT.)}

Table 10. Counterpoise-reviewed Titles That Were Reviewed Ten or More Times in Other Publications

\begin{tabular}{|c|c|c|c|c|}
\hline $\begin{array}{l}\text { LC Main } \\
\text { Class/Subclass } \\
\text { Letters } \\
\end{array}$ & Book Title & LC Subject Headings & Publisher & $\begin{array}{l}\text { Times Reviewed } \\
\text { in Four Core } \\
\text { Library Reviewing } \\
\text { Journals } \\
\end{array}$ \\
\hline HM & $\begin{array}{l}\text { Justice, nature and the geography of } \\
\text { difference }\end{array}$ & $\begin{array}{l}\text { Social ustice. Social change. Social values. Global environmental } \\
\text { change. Cultural relativism. Space and time. }\end{array}$ & Blackwell Publishing & 1 \\
\hline HQ & $\begin{array}{l}\text { Listen up: Voices from the next } \\
\text { feminist generation }\end{array}$ & Feminism—United States. Feminists—United States—Biography. & Seal Press (Seattle) & 3 \\
\hline HQ & $\begin{array}{l}\text { The sex side of life: Mary Ware } \\
\text { Dennett's pioneering battle for } \\
\text { birth control and sex education }\end{array}$ & $\begin{array}{l}\text { Birth control—United States. Sex educators-United States- } \\
\text { Biography. Women social reformers-United States- } \\
\text { Biography. Sex instruction-United States. Women- } \\
\text { biography. Sex Education-United States. Family Planning- } \\
\text { United States. Social Change-United States. }\end{array}$ & New Press (New York) & 2 \\
\hline HT & Exterminate all the brutes & Racism. Racism in literature. & New Press (New York) & 3 \\
\hline HT & $\begin{array}{l}\text { The old neighborhood: What we lost } \\
\text { in the great suburban migration, } \\
\text { 1966-1999 }\end{array}$ & $\begin{array}{l}\text { Cities and towns-United States. Neighborhood-United States. } \\
\text { City and town life-United States. }\end{array}$ & Free Press (New York) & 3 \\
\hline $\mathrm{HV}$ & $\begin{array}{l}\text { Drawing life: Surviving the } \\
\text { Unabomber }\end{array}$ & $\begin{array}{l}\text { Social pathology. Social and public welfare. Criminology } \\
\text { Crimes and offenses. Victims of terrorism-United States- } \\
\text { Biography. Bombings-United States. }\end{array}$ & Free Press (New York) & 3 \\
\hline PS & $\begin{array}{l}\text { Gore Vidal: Sexually speaking: } \\
\text { Collected sex writings }\end{array}$ & $\begin{array}{l}\text { Sex. Sex in literature. Homosexuality in literature. Homosexuality and } \\
\text { literature. English literature-20th century-History and criticism. } \\
\text { American literature-20th century-History and criticism. }\end{array}$ & Cleis (San Francisco) & 1 \\
\hline $\mathrm{RC}$ & $\begin{array}{l}\text { Victims of memory: Sex abuse } \\
\text { accusations and shattered lives }\end{array}$ & $\begin{array}{l}\text { Repression. Crime Victims - psychology. Incest. Child Abuse, } \\
\text { Sexual. Psychotherapy. False memory syndrome. Recovered } \\
\text { memory. Adult child sexual abuse victims. Memory. Repression } \\
\text { (Psychology). }\end{array}$ & $\begin{array}{l}\text { Upper Access } \\
\text { (Hinesburg, Vermont) }\end{array}$ & t) \\
\hline
\end{tabular}


lap, that is, the more often a Counterpoisetitle was reviewed in a category $\mathrm{C}, \mathrm{D}$, or E publication, the greater the chance that it would be reviewed by professional reviewing tools (categories $\mathrm{A}$ and $\mathrm{B}$ ).

On the other hand, from the perspective of a collection development librarian who works outward from a core set of library reviewing tools to an ever-broader universe of journals, the picture is different. The four core library review tools (Booklist, Choice, Library Journal, and Publishers Weekly [category A]) cover only 48.2 percent of all 434 Counterpoise-reviewed titles (209). If this theoretical library professional then expanded her or his range of reading to include what the researchers have called category B publications, she or he would find reviews covering forty additional Counterpoise-reviewed titles. Finally, if a library professional expanded her or his reading range to encompass popular and academic publications (categories C, D, and E), she or he would discover reviews discussing seventy-five additional Counterpoise-reviewed titles, bringing the grand total up to 324 book titles. In other words, the collection development librarian would have to read a very large number of publications (table 4) to receive 74.7 percent ( 324 books out of 434 books reviewed in Counterpoise) of the same information about alternative book titles that is contained in Counterpoise. With regard to book reviews, the role of Counterpoise is therefore not so much one of uniqueness but, rather, one of concentrating information in one place so that a librarian can save time, money, and effort.

However, although Counterpoise reviews almost always tend to be positive in their evaluation of an alternative title, this is not the case with other publication types. For instance, publications in categories C, D, and E collectively evaluate Counterpoise-reviewed books favorably only 55 percent of the time. (See table 6.) This is approximately the same as category B publications (57\% favorable reviews), but far below category A-2 publications, which evaluate Counterpoise-reviewed book titles favorably at a rate of 78.4 percent. Collec- tion development librarians who rely solely on Counterpoise reviews may not receive as objective an evaluation of a particular book title as they may receive from another type of publication.

In addition, collection development specialists who are specifically interested in books that fall under such broad LC classifications as HQ (The family. Marriage. Women), HV (Social pathology. Social and public welfare. Criminology), and E (History: America), as well as fiction titles by members of marginalized groups or those that deal extensively and boldly with sexual topics (such as those in PN and PS classes), should make Counterpoise book reviews required reading, especially if they have been accustomed to exclusively using professional reviewing tools (category A and B publications). (See tables 7 and 8.) Why? As shown in tables 9 and 10, there are often stark differences in both the nature and the publishers of the titles that are not reviewed by category A and B publications and the titles that are frequently reviewed by category A and B publications.

The difference can perhaps best be seen by comparing "Exterminate All the Brutes": One Man's Odyssey into the Heart of Darkness and the Origins of European Genocide (published by New Press in New York) (table 10) with Uprooting Racism: How White People Can Work for Racial Justice (published by New Society Publishers in Gabriola Island, British Columbia) (table 9). The former title concentrates on historical aspects of colonialism and racism in Africa; the latter dissects and offers advice to counteract numerous instances of racism in contemporary life. In other words, Uprooting Racism does not present racism simply as a historical construct but, rather, as an ongoing phenomenon that assumes untold manifestations in even the most seemingly innocuous settings. Similarly, in table 9, the question of sex and sexual orientation is touched on through either historical work, as in The Sex Side of Life: Mary Ware Dennett's Pioneering Battle for Birth Control and Sex Education, or the writings of a renowned and 
prolific intellectual, such as Gore Vidal. Conversely, in table 10, the question of sexual orientation assumes a more radical form, as seen in Body Alchemy: Transsexual Portraits, which is described as an "intensely personal photo documentary of female-to-male transsexuals (FTMs) ... [that] document[s] the transformation of a number of FTMs in [the] transsexual community." 28

\section{Conclusion}

To read some of the editorial statements published in Counterpoise after its break with the ALA is to become aware of the often visceral animosity that exists between Counterpoise editors and what they refer to as the "overarching command structure" of the ALA, a command structure described as "hierarchical, corporate, bureaucratic, self-important and domineering," one that has a proclivity for "elevat[ing] the few and subordinat[ing] the many" and has not supported the efforts of Counterpoise to the degree that Counterpoise believes it should be supported. ${ }^{29,30}$ In many ways, Counterpoise has become a vehicle for a personal crusade against institutional librarianship, what Willett ironically refers to as a constant series of meetings of "big bottoms." 31 There is nothing wrong with this: Anger and frustration often fuel much-needed change. And change seems to be called for because, despite increasing attention to alternative presses, publications of these presses are not being collected to any great extent by OCLC libraries. For instance, 61 of the 114 books (53.5\%) reviewed in Counterpoise in 2001 were held by fewer than 200 OCLC libraries, and 84 of those 114 books $(73.7 \%)$ were held by fewer than 300 OCLC libraries. ${ }^{32}$ Of course, such figures may represent success to some alternative publishers, ${ }^{33}$ but in relation to mass-market best-sellers and well-promoted mainstream titles, these numbers are nevertheless miniscule.

Such statistics are all the more troubling in light of the propensity of chain stores such as Wal-Mart to "typically carry an assortment of fewer than 2,000 books, videos, and albums," "carefully screen content to avoid selling material likely to offend their conservative customers," and be ruthless about returning goods "if they fail to meet a minimum threshold of weekly sales." ${ }^{34}$ Not only has Wal-Mart banned books by Kurt Cobain, it has been instrumental in helping to "produce a string of best sellers by conservative authors like Bernard Goldberg, Ann Coulter, Michael Savage and Bill O'Reilly" and contributed to the decision of AOL TimeWarner to start a religious imprint "because a book buyer for Wal-Mart [said] that more than half its sales were Christian books." 35 Because mass merchandisers such as Wal-Mart accounted for 12.6 percent of all books sold in the United States in 2002 (up from 9.1\% in 1992) and for "more than 40 percent for a best-selling book," their growing influence "has bent American popular culture towards the tastes of their relatively traditional customers." ${ }^{36}$ If the tactics of stores such as Wal-Mart lead to an increasing level of homogenization in the number and types of books available for public consumption, the role of the library, whether academic or public, as a provider of alternative voices becomes all the more crucial, especially because Wal-Mart supported books typically become best-sellers, which increases the likelihood that these titles will make their way to library shelves.

And if the example of the Minneapolis Community and Technology College (MCTC), which now spends 10 percent of its materials budget on alternative press resources, is taken into consideration, Counterpoise has had a significant positive effect on the ability of colleges and universities to collect alternative press publications. ${ }^{37}$ At the same time, as the present study has demonstrated, numerous other publications, including mainstream magazines and newspapers, review alternative press book titles, and a significant majority of those reviews are favorable. For the most part, those reviews appear before reviews appear in Counterpoise. The four core library reviewing publications review 
48.2 percent of Counterpoise-reviewed titles, with 74.4 percent of the reviews being favorable. When a collection development librarian supplements the four core library reviewing publications with other publications, even more reviews of alternative press titles become available. In summation, information about such titles is readily available to those librarians who read widely and extensively in a variety of library reviewing tools, popular magazines, and academic journals. When all is said and done, it is not libraries who purchase books, but individual librarians who purchase books on behalf of their institutions. If libraries do not own a large number of alternative press titles, and if there are nevertheless numerous reviews about such titles in a wide variety of publications that are ostensibly read by collection development librarians, the reason for a lack of alternative press titles in libraries lies more with uninterested and unaware individual librarians who do not read widely (or who rely on approval plans) than with the libraries for which these individuals work and the organizational structures that bring these libraries together.

To be sure, adequate financial resources are necessary to buy alternative titles. But adequate financial resources also are necessary to buy any type of titles. Ultimately, it is the decision of individual collection development librarians that makes the difference. The example of MCTC is instructive in this respect. When the Minnesota state legislature granted academic libraries additional funds with the proviso that 20 percent of those funds be used "to build collections in unique subject areas, ${ }^{\prime \prime 38}$ staff of MCTC could have spent their allotment on any type of materials. They did not do so, choosing, instead, "as a result of the extra money, and other decisions made by the staff," to systematically devote 10 percent of their materials budget to alternative press materials. . $^{39,40}$

To judge by the 1,225 reviews of Counterpoise-reviewed titles in other publications, at the beginning of the twenty-first century interest in the publications of alternative and small presses has reached a critical mass in publications of all types, not just Counterpoise. Accordingly, the failure of libraries to own books published by alternative and small presses may be a reflection of the disinterest that individual librarians have for questions surrounding the issue of corporate control of cultural industries, a failed understanding of the true implications of balance and neutrality (vaunted principles underlying collection development work) in an era where organizations such as Wal-Mart shape cultural tastes through their book merchandising policies, and a disinclination to read widely in order to find out about as many books as possible on a given topic so as to be able to make informed and socially responsible decisions about book purchases. But the case of MCTC shows that local, small-scale efforts can have a large impact. Of course, it would have been easy for MCTC staff members (or others like them) to blame the dearth of alternative press titles in their library's collection on the inflexibility of (or gaps inherent in) approval plans, cutbacks forced by restrictions in the current budget, the ever-present need to develop core collections in teaching areas, or perceived administrative disapproval of purchases of titles that do not have the imprimatur of recognized and esteemed publishers or authors. But they did not elect to do so, instead taking it upon themselves as individuals to act.

\section{Notes}

1. Civic Media Center. Available online from http://www.civicmediacenter.org/counterpoise/. (Accessed 16 May 2002.)

2. Charles Willett, "Editor's Notes," Counterpoise 4 (July 2000): 4.

3. Civic Media Center. Available from http://www.civicmediacenter.org/counterpoise/. (Accessed 16 May 2002.)

4. Willett, "Editor's Notes."

5. "Counterpoise Business Plan: FY 2001, Part I: Mission Statement," Counterpoise 4 (Jan. / Apr. 
2000): 4 .

6. Ibid.

7. Ibid.

8. Willett, "Editor's Notes."

9. Ibid.

10. Ibid. Willett quotes Herman.

11. Ibid.

12. Ibid.

13. Ross Atkinson, "The Citation as Intertext: Toward a Theory of the Selection Process," Library Resources \& Technical Services 28 (Apr. 1984): 113.

14. Judith Serebnick and John Cullars, "An Analysis of Reviews and Library Holdings of Small Publishers' Books," Library Resources E Technical Services 28 (Jan. 1984): 4-14.

15. Judith Serebnick, "Selection and Holding of Small Publishers' Books in OCLC Libraries: A Study of the Influence of Reviews, Publishers, and Vendors," Library Quarterly 62 (July 1992): 259-94.

16. Ibid., $275,276$.

17. Ibid., 277.

18. Juris Dilevko and Alison Hayman, “Collection Development Patterns of Fiction Titles in Public Libraries: The Place of Independent and Small Presses," Library $\mathcal{E}$ Information Science Research 22 (2000): 35-59.

19. Ibid., 43.

20. See Serebnick, "Selection and Holding," 264.

21. Tom Person, "The Surviving Small Press: What Is Small Press?" Available online from http://www.laughingbear.com/articles/137_what_is_small_press.html. (Accessed 12 September 2003.)

22. Ibid.

23. Michael Albert, "What Makes Alternative Media Alternative?" Available online from http:/ /whorlpool.905host.net/files/edarchive10.htm. (Accessed 12 September 2003.)

24. Subsequent uses of the term "alternative" in this article should be interpreted in light of the editorial statements appearing in Counterpoise, which have been discussed in the opening paragraphs of this article.

25. As one of the reviewers of this article pointed out, we may be naïve in our assumption that collection development librarians rely on reviews (in any publication, including Choice) to any great extent for collection development purposes. We acknowledge, as this reviewer noted, that many librarians rely "almost exclusively" on approval plans and that approval plans "select books prior to the publication of reviews making them [the reviews] irrelevant regardless of where they are published." We would like to think, however, that reviews do serve an important purpose in decisions about what to purchase or what not to purchase and that librarians are not, as this reviewer observed, "lazy."

26. As pointed out by one of the reviewers of this article, it may not be appropriate to exclude zines and other nonbook formats in any analysis of the content of Counterpoise because zines and other nonbook formats are an integral part of the universe of alternative publications and of Counterpoise.

27. Although we recognize that there is a debate about whether ProQuest ratings are misleading, ProQuest is, to our knowledge, one of the only tools that provides a readily quantifiable rating of reviews.

28. Cleis Press. Available online from http://www.cleispress.com/Pages/bodyalchemy.html. (Accessed 19 May 2003.)

29. Willett, "National Structures Do Not Represent American Librarians," Counterpoise 5 (July/ Oct. 2001): 4 .

30. $\longrightarrow$, "Editor's Notes."

31. - "National Structures Do Not Represent American Librarians," 4.

32. Earl Lee, "OCLC Holdings of Books Reviewed in Counterpoise," Counterpoise 6 (Jan./ Apr. 2002): 18-20.

33. We thank both reviewers for bringing this point to our attention. And, as the reviewers also pointed out, print runs for alternative press publications are typically small and may result in low levels of holdings of these titles in OCLC libraries. In addition, numerous libraries have sizable original cataloging backlogs, and so they may not have been able to upload originally cataloged records of alternative publications to OCLC in a timely manner, which results in OCLC undercounts. Both these observations should be kept in mind when looking at these, or any other, OCLC statistics.

34. David D. Kirkpatrick, "Shaping Cultural Tastes at Big Retail Chains," New York Times (May 18, 2003): B1, B7. 
Reviews of Independent Press Books in Counterpoise and Other Publications 77

35. Ibid., B7.

36. Ibid., B1.

37. Tom Eland, "Letters \& Messages," Counterpoise 4 (July 2000): 2.

38. Ibid.

39. Ibid.

40. The question of why MCTC staff members only began to purchase alternative press publications after a funding increase is a very valid one, and we thank one of the reviewers of this article for bringing it to our attention. 